\title{
Detection of Rutin, Kaepferol, and Quercetin based Crude from Corn Silk and Studying their Effects on the Inhibition of Pure Urease Enzyme and Urease of Klebsiella Species
}

\author{
Rafah H. Ismael ${ }^{1 *}$, Salman A. Ahmed ${ }^{1}$ and Suhad S. Mahmoud ${ }^{2}$ \\ ${ }^{1}$ Department of chemistry, Collage of Science, Al-Nahrain University, Baghdad, Iraq \\ ${ }^{2}$ Department of Biotechnology, College of Science, University of Baghdad, Baghdad, Iraq \\ *Corresponding author
}

\section{A B S T R A C T}

\begin{tabular}{|c|c|}
\hline & This paper was carried out for detection of Rutin, Kaepferol, and Quercetin in corn silk, \\
\hline Keywords & $\begin{array}{l}\text { Klebsiella species urease. An HPLC has been used to detect the three flavonoid } \\
\text { components in three extracts of corn silk (using } 99.9 \% \text { ethanol, } 80 \% \text { ethanol and water). }\end{array}$ \\
\hline $\begin{array}{l}\text { Ethanol, Flavonoid, } \\
\text { Urease inhibition, } \\
\text { HPLC, Rutin, } \\
\text { Quercetin, Kaepferol. }\end{array}$ & $\begin{array}{l}\text { The results were }(0.012 \mathrm{mg} / \mathrm{L}) \text { of Quercetin in } 99.9 \% \text { ethanolic extract }(99.9 \% \mathrm{EE}) .(0.1398 \\
\mathrm{mg} / \mathrm{L}),(0.15 \mathrm{mg} / \mathrm{L}) \text {, and }(0.11 \mathrm{mg} / \mathrm{L}) \text { of Rutin, Kaepferol, and Quercetin respectively in } \\
80 \% \text { ethanolic extract }(80 \% \mathrm{EE}) .(0.071 \mathrm{mg} / \mathrm{L}) \text { and }(0.091 \mathrm{mg} / \mathrm{L}) \text { of Rutin and Kaepferol } \\
\text { respectively in aqueous extract }(\mathrm{AE}) \text {. It is noticed that only } 80 \% \text { ethanol has an ability to }\end{array}$ \\
\hline Article Info & $\begin{array}{l}\text { extract such three flavonoids. All such extracts revealed an effective inhibition of urease } \\
\text { enzyme in the Klebsiella species with (IC50 }=77.06,13.54+- \text { and } 35.93 \mathrm{mg} / \mathrm{L} \text { ) for } 99.9 \%\end{array}$ \\
\hline $\begin{array}{l}\text { Accepted: } \\
\text { 20 September } 2017 \\
\text { Available Online: } \\
10 \text { November } 2017\end{array}$ & $\begin{array}{l}\text { ethanol, } 80 \% \text { ethanol and aqueous extracts respectively, while standard urease inhibitor } \\
\text { exhibits (IC50 = } 453.4 \mathrm{mg} / \mathrm{L} \text { ) for thiourea (TU) as an example. Lastly, such extracts were } \\
\text { utilized in the inhibition of pure enzyme and they exhibited an efficient inhibition of (IC50 } \\
=402.8,95.8 \text {, and } 348 \mathrm{mg} / \mathrm{L} \text { ) for } 99.9 \% \text { ethanol, } 80 \% \text { ethanol and aqueous extracts }\end{array}$ \\
\hline & $\begin{array}{l}\text { respectively as compared with standard urease inhibitor of which gives }(\text { IC50 }=54077 \\
\mathrm{mg} / \mathrm{L} \text { ) in thiourea (UT). }\end{array}$ \\
\hline
\end{tabular}

\section{Introduction}

\section{Corn silk}

Corn silk is a long, weak, and shiny fibers at the top of corn's ear (1). Traditionally, it is used for making tea as a healthy and medical drink in Asian communities especially in China (2). Recently, corn silk becomes very important in drugs development, because of its bioactive constituents which include oxidant prevention agent limits, anti-diabetic activity anti-proliferative effects diuretic activity anticoagulant activity, antifungal, anti-fatigue, and treating obesity (3).

In addition, corn silk has been used as a treatment of many diseases like hyperglycemia, hypertension, cystitis, tumor, hepatitis, gout, diabetes, kidney stones, prostatitis, and nephritis (4). Moreover, it is used medicinally as a mellow stimulant, diuretic, and demulcent. It is helpful in intense and incessant cystitis and in the 
bladder aggravation of uric corrosive, phosphatic grave, and employed in Gonorrhea (5). According to the phytochemical studies on corn silk, it revealed that corn silk contains a number of components like protein, vitamin, some minerals $(\mathrm{Ca}, \mathrm{K}, \mathrm{Mg}, \mathrm{Mn}$, and $\mathrm{Zn})$, flavonoids, steroid, carbohydrate and volatile components $(4,6)$. Besides that, it contains chlorogenic acid, p-coumaric, ferulic acid, saponins, phytosterols, volatile oil, fixed oil, resin, sugars, allantoin, and tannin (5).

\section{Flavonoids}

Physiologically, Flavonoids (the original term is a Latin name called "flavus" word; which means yellow) play a vital role as the major former of blue, red, and purple pigments of plants tissues (7). Phenol was considered as a dominant component in flavonoid formation, the three carbon atoms were formatted for connecting two rings of phenol to form a heterocyclic ring by joining them with an oxygen atom (8). Flavonoids are the essential group of polyphenolic. They exhibit important effects on radicals' scavengers and health strengthen properties. Polyphenols have abilities to inhibit free radicals, to decrease the cardiovascular problems, and to produce a strong anti-inflammatory and anticancer activity (9). Flavonoids effectively used to treat the obesity, hypertension, and dyslipidemia in both humans and animals (10). Flavonoids fall into several types like flavones, flavanones, anthocyanins isoflavones, and flavonols (11).

\section{Quercetin}

It is a plant polyphenol belongs to flavonol of flavonoids. Mostly, It's available in many human foods especially fruits, leaves, grains, and vegetables (12). It characterizes by a phenyl benzo (c) pyrone derived structure as represented by its chemical structure shown in figure 1 (13).

\section{Rutin}

It is the glycoside which combine the disaccharide rutinose ( $\alpha$-L-rhamnopyranosyl$(1 \rightarrow 6)-\beta$-D-glucopyranose) and the flavonol quercetin (10). Lots of researches proved the significant effects on preventing several types of diseases (14). It has several pharmacological characteristics like antiinflammatory, antioxidant, anti-carcinogenic, antiviral, antiallergic, and stronge scavenger of superoxide radicals (15). The chemical structure of rutin is exhibited in figure 2 .

\section{Kaepferol}

It is known as a natural flavonol (one of the flavonoids type). It is one of the most common food flavonoids; initially, it found in tea propolis, and grape fruit (16). It is popular due to its antioxidant activity and his efficient utilization in cytoprotection agents. Previous experiments revealed that Kaepferol produces anti-proliferation activity and contains apoptosis in a variety of human cancer cell lines in vitro, for examples, leukemia, and cancers related to non-small cell lung, prostate, esophageal, cell lung, colon, oral cavity (15). Figure 3 presents the chemical structure of Kaepferol.

\section{Klebsiella species}

It is a gram negative bacterium in the family of Enterobacteriaceae. It is heavily dispersed in water, air, and soil. It forms a part of the normal microbiota which exists in human and animal gastrointestinal and urinary tracts (17).

It produces urease enzyme which hydrolysis of urea and its last items being alkali and carbonic acid (18). Ureases are multi-subunit of nickel-containing enzymes (19). They are playing very important role in several pathological situations such as gastric cancers, peptic ulcers, hepatic 
encephalopathy, urinary catheter encrustation, and urolithiasis. Its inhibition, therefore; has a major therapeutic (20). However, Ureases inhibited by numbers of compounds such as hydroxamic acids, phosphoramidites, and imidazoles. Several studies of inhibition have been carried out to investigate the molecular mechanism of urease activity moreover to assure compounds that could effectively control its activity (18).

\section{Materials and Methods}

\section{Extraction from corn silk}

The samples of corn plant were collected at harvesting time where their materials are fully maturated and developed. Firstly, the corn silk flowers were gathered from corn fields of the faculty of Agriculture's farm of Baghdad University in February 2017. Secondly, they were dried in a shaded well-ventilated place. Thirdly, pulverizing them using a knife mills then keeping them stored in glass containers at room temperature for further processing (21). A $100 \mathrm{~g}$ of pulverized corn silk were exposed to a hot continuous extraction by Erlenmeyer flask in a Ultrasonic with $1 \mathrm{~L}$ of (99\% ethanol, $80 \%$ v/v ethanol/water and water) $(3 * 5 \mathrm{~L})$ at steady temperature of $(50 \pm$ $1.0{ }^{\circ} \mathrm{C}$ ) for three cycles of 5 hours periods for each. Each of three previous extracts was filtered through Whatman No. 1 filter paper to remove the debris. Then, each filtered sample was condensed by a rotary flash evaporator under vacuum at $50^{\circ} \mathrm{C}$. Finally lyophilizing each condensed samples in a freeze-dryer to obtain a crude ethanol Extract (EF), 80\% ethanolic extract, and water extract. Lastly, all extracts were stored at $4{ }^{\circ} \mathrm{C}$ for subsequent analysis (12). The below equation used to determine the yield as percentage of the quantity of the initial material of $(100 \mathrm{~g})$.

Yield $\%=\frac{\text { yield } * 100}{100 \mathrm{~g}}$

\section{Detection some flavonoids by HPLC}

A $0.1 \mathrm{~g}$ of each crude was dissolved in methanol of volume $100 \mathrm{~mL}$. A $20 \mu \mathrm{L}$ of each dissolved was filtered through $0.45 \mu \mathrm{m}$ membrane then analyzing them for detecting the compounds (Rutin, Kaepferol, Quercetin, and Maysin) using reversed phase HPLC, column $=(250 * 4.6 \mathrm{~mm}$ Id $) 5 \mathrm{~mm}$ particle size. Then diluting with methanol-water (80 to $100 \%$ and methanol with $1 \%$ Orthophosphoric acid.

The UV-Vis detector set at $280 \mathrm{~nm}$. A $0.1 \mathrm{~g}$ of each crude was dissolved in methanol of volume $100 \mathrm{~mL}$. A $20 \mu \mathrm{L}$ of each dissolved was filtered through $0.45 \mu \mathrm{m}$ membrane then analyzing them for detecting the compounds (Rutin, Kaepferol, Quercetin, and Maysin) using reversed phase HPLC, column= $(250 * 4.6 \mathrm{~mm} \mathrm{Id}) 5 \mathrm{~mm}$ particle size. Then diluting with methanol-water (80 to $100 \%$ ) and methanol with $1 \%$ Orthophosphoric acid. The UV-Vis detector set at $280 \mathrm{~nm}$.

The place of flavonoids in the HPLC results was defined through comparing the peak retention time between extracts and standard flavonoids solution; (retention time of compound Rutin, Kaempferol, and Quercetin were $2.85,3.08$, and $7.31 \mathrm{~min}$; respectively).

The content of flavonoids was calculated through regression equation between peak area and flavonoids content (8).

\section{Preparation concentration}

To prepare the stock solutions; initially, all extracts were dissolved with phosphateBuffered ( $\mathrm{PH}=7)$. Then, diluting the previous concentrations of $(1000,500,250,125$, and 62.5) $\mathrm{mg} \backslash \mathrm{L}$ with phosphate-Buffered $(\mathrm{PH}=7)$. At the end, all extracts were filtered with a micro filter of $0.45 \mu \mathrm{m}$ then storing them at 4 ${ }^{\circ} \mathrm{C}$ for further use. 


\section{Activation of microorganisms}

The specimen of the colonies was taken by a loop that contains $5 \mathrm{ml}$ of sterilized nutrient broth. The loop has been shaken well and incubated in the incubator for 24 hours at 37 ${ }^{\circ} \mathrm{C}$. The loop was sterilized via flame before using it to ensure that the planted bacteria are not contaminated.

\section{Klebsiella species urease inhibition assay}

Dissolve $38.71 \mathrm{~g}$ of urea broth powder in $1000 \mathrm{ml}$ distilled water. Then, thoroughly mix to dissolve the medium completely then sterilize the results by Autoclave. After that, $40 \%$ urea was sterilized by filtration. After activation, under a sterile tube and aseptic ambience, the desired colony was taken by a loop to the test tube that contains $5 \mathrm{ml}$ of the sterilized urea broth.

The inhibition of urease examination was performed spectrophotometrically in 96-well Microplate. The solution: $(100 \mu l)$ of bacteria diluted of Klebsiella species was incubated with $100 \mu 1$ of Extracts (99.9\% EE), (80\% $\mathrm{EE})$, and (AE) in concentrations of $(1000$, $500,250,125,62.5$, and $31.25 \mathrm{mg} / \mathrm{L})$ at $30^{\circ} \mathrm{C}$ for 24 hour. Thereafter, Urease activity was continuously measured with the rate of ammonia generation, and change in absorbance (optical density) was measured at $630 \mathrm{~nm}$ on ELISA plate reader in Compare with standard urease inhibitor i.e. thiourea (TU) (20).

\section{Urease inhibition assay in pure enzyme}

The urease inhibition assay has been run spectrophotometrically in 96-well plate. A phosphate buffer ( $\mathrm{pH} 6.8 ; 4 \mathrm{mM}$ ) has been used to dissolve solution of urease enzyme. The net reaction volume was $200 \mu \mathrm{L}$. A $25 \mu \mathrm{L}$ of urease enzyme incubated with $5 \mu \mathrm{L}$ of Extracts $(99.9 \% \mathrm{EE}),(80 \% \mathrm{EE})$, and $(\mathrm{AE})$ in concentration $(1000,500,250,125,62.5$, and $31.25 \mathrm{mg} / \mathrm{L}$ ) at $30{ }^{\circ} \mathrm{C}$ for 15 minutes. After that, Urea $(55 \mu \mathrm{L} ; 100 \mathrm{mM})$ was added and the plate was incubated again at $30^{\circ} \mathrm{C}$ for 10 minutes. After incubation, the results added to each well $70 \mu \mathrm{L}$ of alkali reagents (sodium hydroxide $(0.5 \% \quad \mathrm{w} / \mathrm{v})$ and sodium hypochlorite $(0.1 \%))$ and $45 \mu \mathrm{L}$ of phenol (pheno1 $(\% \mathrm{w} / \mathrm{v})$ and sodium nitroprusside $(0.005 \% \mathrm{w} / \mathrm{v}))$; The plate was again incubated at $30{ }^{\circ} \mathrm{C}$ for 50 minutes. The activity of urease was continuously estimated with the rate of release of ammonia, and the absorbance changing (optical density) was observed at $360 \mathrm{~nm}$ on ELISA plate reader. Thiourea used as a standard compound (20).

\section{Statistical analysis}

All experiments were carried out in triplicate. The results were processed via Microsoft excel. The percentage of inhibition was calculated by using the formula given below.

$\%$ Inhibition $=100-\left\{\frac{\text { Absorbance of Test Compound }}{\text { Absorbance of Control }} \times 100\right\}$

Measuring the effects of different concentrations of inhibitors on production of ammonia was used to evaluate the IC50 of the active compounds. The IC50 values were determined using Graphpad Prism7 software.

\section{Results and Discussion}

\section{Plant extract}

The yields of corn silk's extracts with respect to the solvent are shown in table 1 . The percentage of yields calculated according to $100 \mathrm{~g}$ of corn silk for each extraction method.

According to the results shown in table 1, it is noticed that the water solvent gives higher yield than others which can considered as factor in solvent cost reduction. 
Table.1 The extracted yields for every relevant solvent

\begin{tabular}{|c|c|c|}
\hline $\begin{array}{c}\text { Type of solvents } \\
\text { used in extraction }\end{array}$ & Yield(g) & yield\% \\
\hline $99.9 \%$ ETHANOL & 0.93 & $0.93 \%$ \\
\hline $80 \%$ ETHANOL & 2.4 & $2.40 \%$ \\
\hline WATER & 9.13 & $9.10 \%$ \\
\hline
\end{tabular}

Table.2 Concentrations of (Rutin, Kaepferol and Quercetin) in (99.9\%EE) (80\%EE), and (AE)

\begin{tabular}{|c|c|c|c|c|}
\hline $\begin{array}{c}\text { Type of } \\
\text { flavonoids }\end{array}$ & $\begin{array}{c}\text { R time } \\
\text { (min.) }\end{array}$ & $\begin{array}{c}\text { Concentration in } \\
99.9 \% \text { ETHANOL } \\
\text { extract (mg/L) }\end{array}$ & $\begin{array}{c}\text { Concentration } \\
\text { in 80\% } \\
\text { ETHANOL } \\
\text { extract (mg/L) }\end{array}$ & $\begin{array}{c}\text { Concentration in } \\
\text { aqueous extract } \\
(\mathrm{mg} / \mathrm{L})\end{array}$ \\
\hline Rutin & 2.851 & - & 0.1398 & 0.071 \\
\hline Kaepferol & 3.08 & - & 0.15 & 0.091 \\
\hline Quercetin & 7.315 & 0.012 & 0.11 & - \\
\hline
\end{tabular}

Table.3 Klebsiella species urease inhibitory activity of Extracts (99.9\%EE) (80\%EE), (AE) as compared with standard urease inhibitor thiourea (TU)

\begin{tabular}{|c|c|c|c|c|}
\hline $\begin{array}{c}\text { conc. } \\
\text { (mg/L) }\end{array}$ & $\begin{array}{c}\text { Inhibition\% } \\
\text { of (TU) }\end{array}$ & $\begin{array}{c}\text { Inhibition\% } \\
\text { of.(99.9\%EE) }\end{array}$ & $\begin{array}{c}\text { Inhibition\% } \\
\text { of(80\%EE) }\end{array}$ & $\begin{array}{c}\text { Inhibition\% } \\
\text { of (AE) }\end{array}$ \\
\hline 31.25 & 29.78 & 23.72 & 9.92 & 28.81 \\
\hline 62.5 & 34.62 & 29.53 & 23.97 & 34.62 \\
\hline 125 & 38.25 & 33.89 & 31.23 & 37.77 \\
\hline 250 & 39.7 & 38.98 & 32.62 & 39.22 \\
\hline 500 & 45.76 & 41.64 & 36.25 & 40.67 \\
\hline 1000 & 52.3 & 44.33 & 42.42 & 44.3 \\
\hline
\end{tabular}

Table.4 IC50+SEM inhibitor in Klebsiella species urease

\begin{tabular}{|c|c|}
\hline Type of inhibitor & $\begin{array}{c}\text { IC50+SEM(mg/L) (inhibitory in } \\
\text { Klebsiella Species urease) }\end{array}$ \\
\hline Thiourea (TU) & $453.4 \pm 1.84$ \\
\hline $\begin{array}{c}\text { 99\% ethanol } \\
\text { extraction(99.9EE) } \\
80 \% \text { ethanol } \\
\text { extraction(80\%EE) }\end{array}$ & $77.06 \pm 1.19$ \\
\hline $\begin{array}{c}\text { Aqueous } \\
\text { Extraction (AE) }\end{array}$ & $35.94 \pm 4.02 .37$ \\
\hline
\end{tabular}


Table.5 Urease inhibitory activity of extracts $(99.9 \% \mathrm{EE}),(80 \% \mathrm{EE})$, and (AE) in comparative to standard urease inhibitor i.e. thiourea (TU)

\begin{tabular}{|c|c|c|c|c|}
\hline $\begin{array}{c}\text { Concentration } \\
(\mathrm{mg} / \mathrm{L})\end{array}$ & $\begin{array}{c}\text { Inhibition } \\
\% \text { of (TU) }\end{array}$ & $\begin{array}{c}\text { Inhibition \% } \\
\text { of.(99.9\%EE) }\end{array}$ & $\begin{array}{c}\text { Inhibition\% } \\
\text { of }(80 \% \mathrm{EE})\end{array}$ & $\begin{array}{c}\text { Inhibition\% } \\
\text { of (AE) }\end{array}$ \\
\hline 31.25 & 37.65 & 33.77 & 33.4 & 33.61 \\
\hline 62.5 & 39.64 & 35.08 & 36.1 & 36.18 \\
\hline 125 & 42.31 & 38.07 & 39.9 & 37.65 \\
\hline 250 & 45.2 & 39.17 & 41.26 & 39.95 \\
\hline 500 & 46.51 & 43.36 & 42.42 & 44.57 \\
\hline 1000 & 57.99 & 46.3 & 45.98 & 46.82 \\
\hline
\end{tabular}

Table.6 IC50+SEM inhibitor in pure urease enzyme

\begin{tabular}{|c|c|}
\hline Type of inhibitor & IC50+SEM(mg/L) (inhibitory in pure urease enzyme) \\
\hline Thiourea (TU) & 54077 \\
\hline 99\%ethanol extraction(99.9EE) & 402.8 \\
\hline 80\%ethanol extraction(80\%EE) & 95.8 \\
\hline Aqueous extraction (AE) & 348 \\
\hline
\end{tabular}

Fig.1 Chemical structure of Quercetin<smiles>O=c1c(O)c(-c2ccc(O)c(O)c2)oc2cc(O)cc(O)c12</smiles>

Fig.2 The chemical structure of Rutin

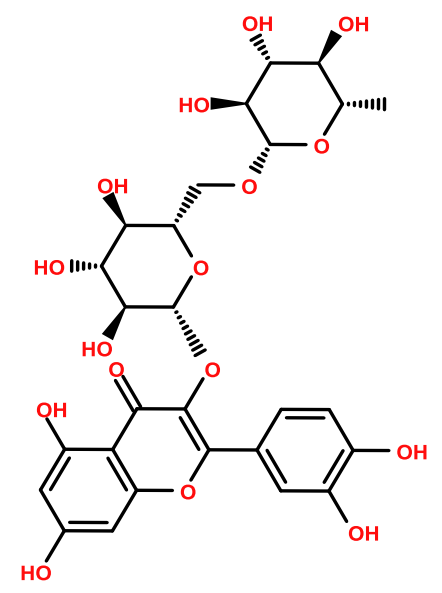


Fig.3 Chemical structure Kaepferol<smiles>O=c1c(O)c(-c2ccc(O)cc2)oc2cc(O)cc(O)c12</smiles>

Fig.4 HPLC of standard flavonoids (retention time of Rutin, Kaepferol, and Quarcetin, were $2.85,3.08$, and $7.31 \mathrm{~min}$, respectively)

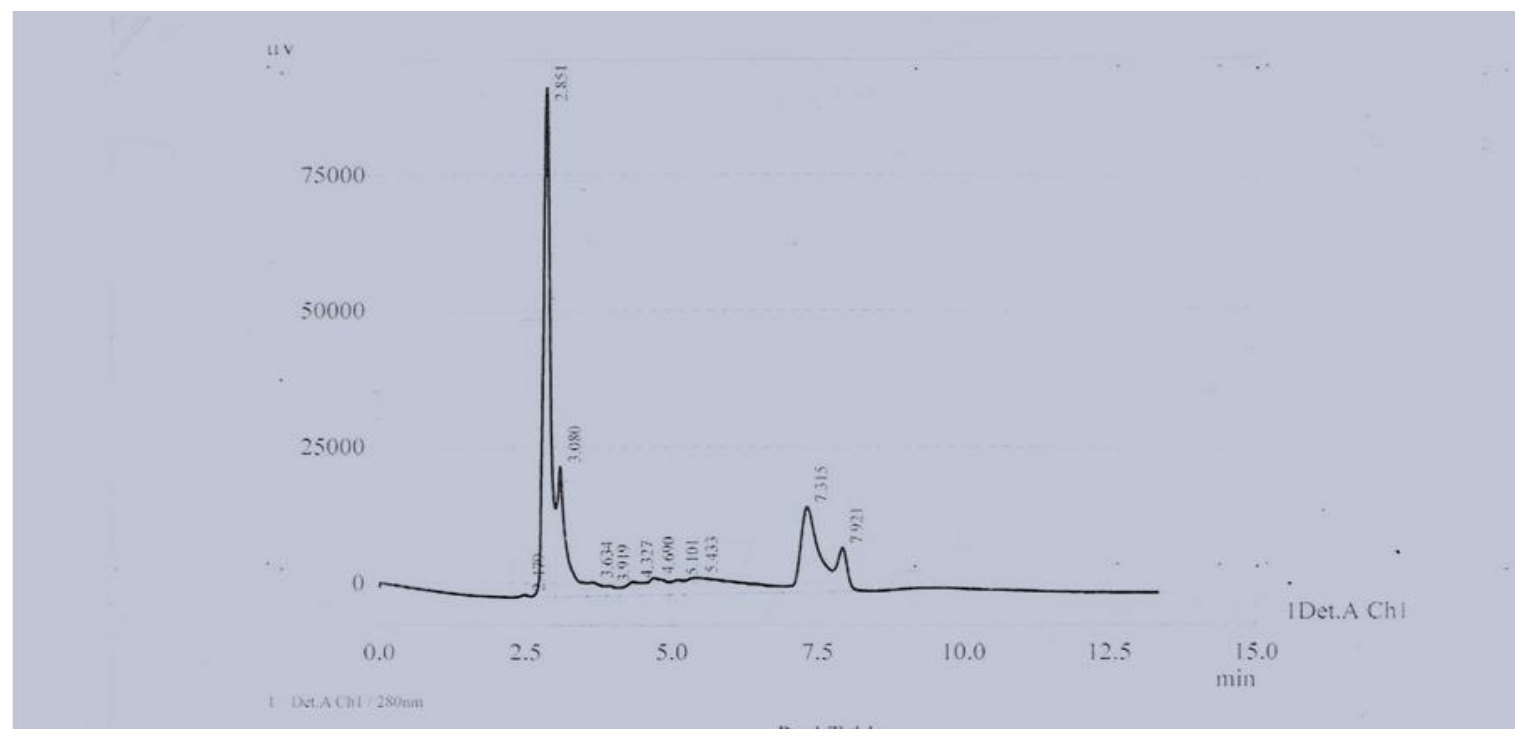

Fig.5 HPLC of $99.9 \%$ ethanolic extract

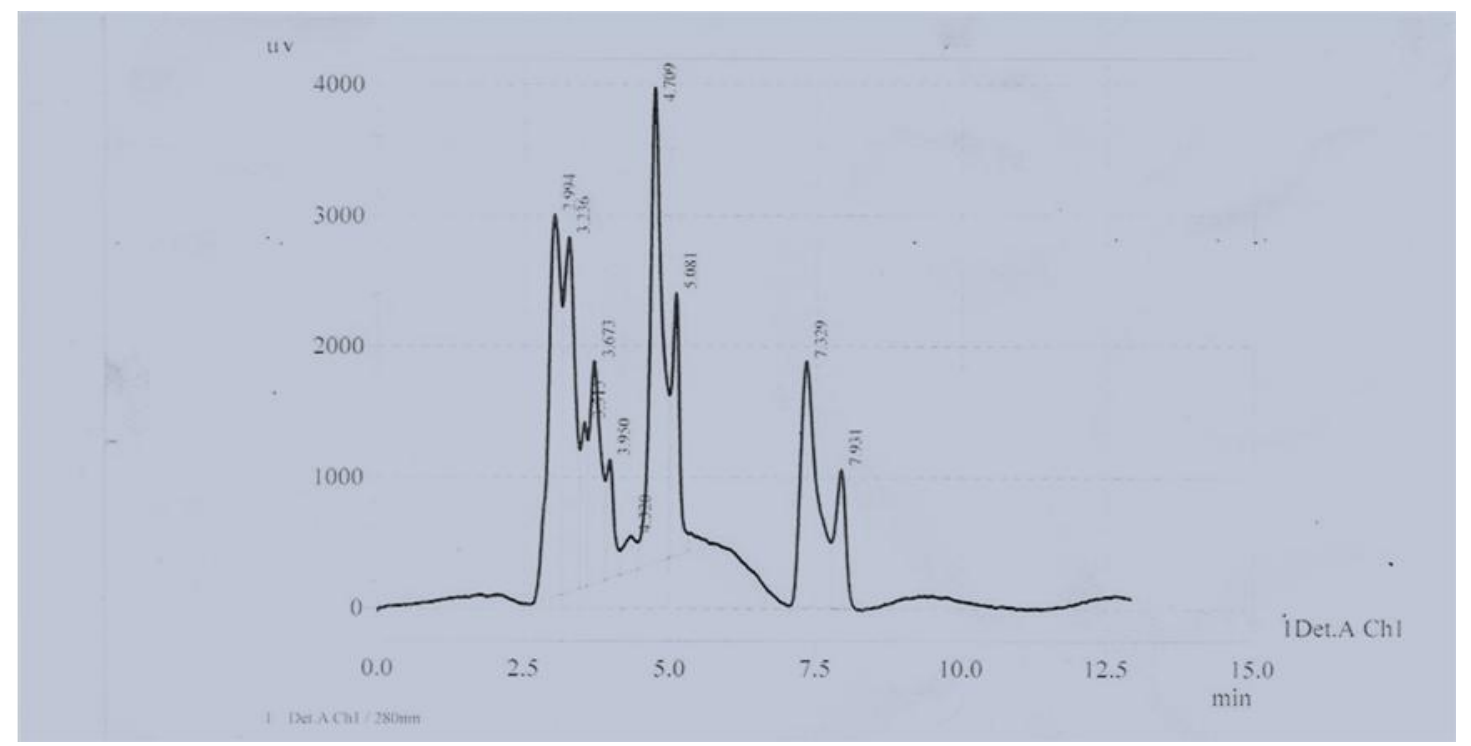


Fig.6 HPLC of $80 \%$ ethanolic extract

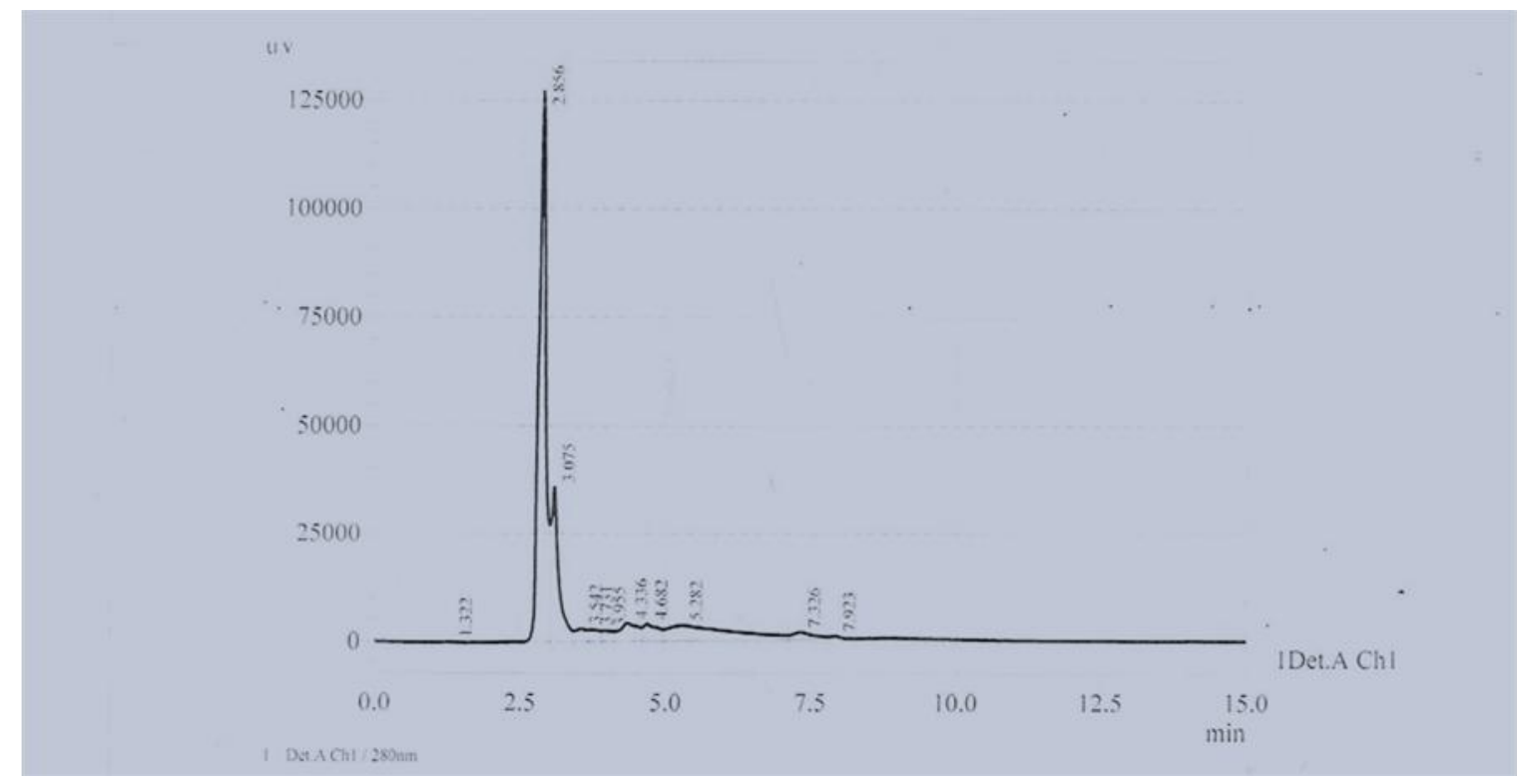

Fig.7 HPLC of water extract

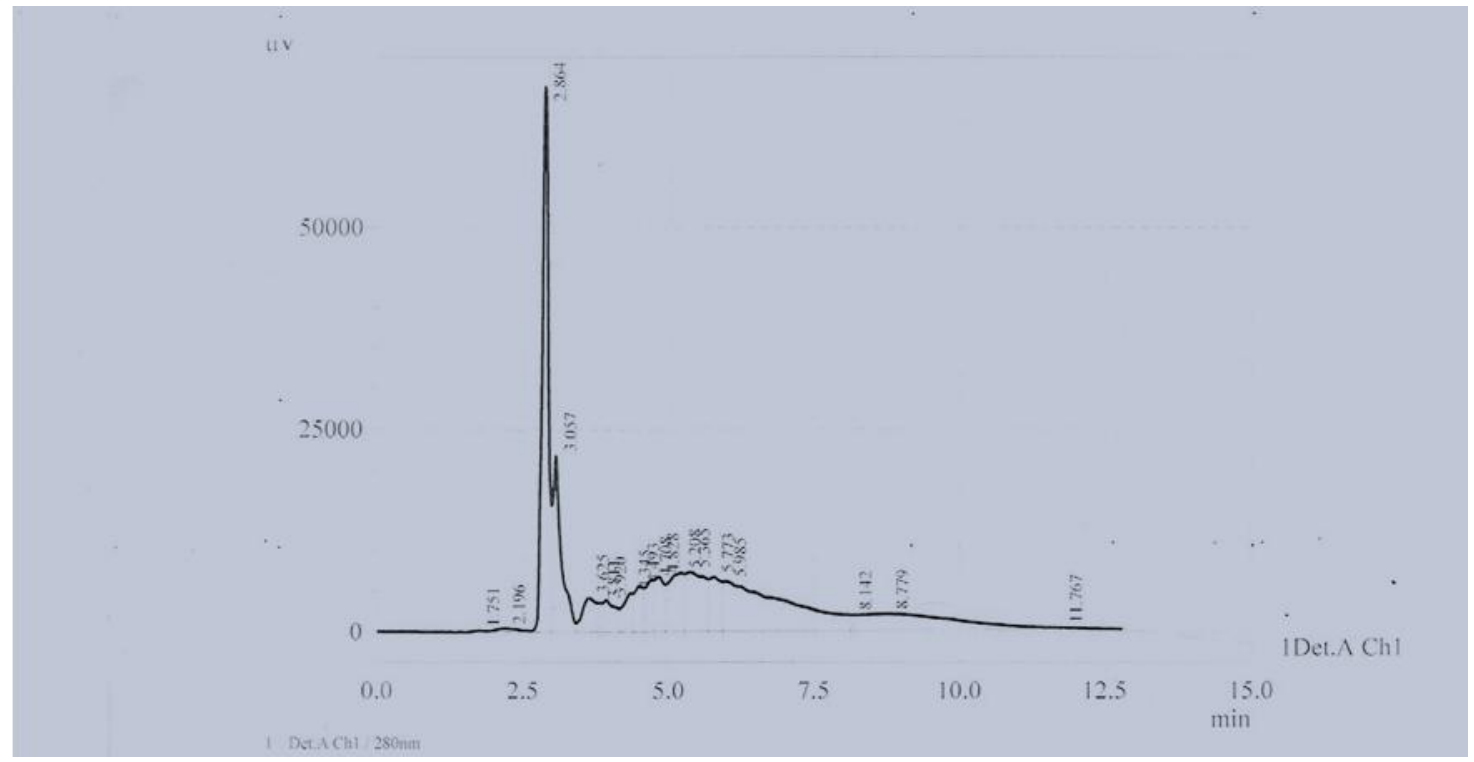

\section{Detection some flavonoids by HPLC}

The results of three flavonoids detection using reversed phase HPLC are exhibited in the table 2 and shown in Figures 4, 5, 6 and 7). The results of (Rutin, Kaempferol and, Quercetin) concerning flavonoids constitution of corn silk extracts were: $(0.012 \mathrm{mg} / \mathrm{L})$ of Quercetin in $99 \%$ ethanolic extract, (0.13,
0.15 and, $0.11 \mathrm{mg} / \mathrm{L}$ ) of (Rutin, Kaempferol, and Quercetin) respectively in $80 \%$ ethanolic extract, and (0.071, $0.091 \mathrm{mg} / \mathrm{L}$ ) of (Rutin, and Kaempferol) respectively in aqueous extract. It is seen that $80 \%$ ETHANOL gives better and higher concentrations than others and it is suitable for all three types of flavonoids. 


\section{Urease inhibitory activity in Klebsiella Species}

The inhibitory activity of Extracts (99.9\%EE), (80\%EE), and (AE) to Klebsiella species are shown in the table 3. It is noticed that all three extracts (99.9\%EE), (80\%EE), and (AE) show a potent urease inhibitory activity (IC50 $=77.06 \pm 1.19,13.54 \pm 4.02$, and $35.93 \pm 2.37$ $\mathrm{mg} / \mathrm{L}$ ) respectively as compared with Thio urea which shows inhibitory of (IC50 $=453.4$ $\pm 1.84 \mathrm{mg} / \mathrm{L})$.

The IC50 Values of Extracts and the standard thiourea as urease inhibitor in Klebsiella species urease are shown in table 4.

\section{Urease inhibitory activity in pure enzyme}

Table 5 shows the pure inhibitory activity of the three extracts $(99.9 \% \mathrm{EE}),(80 \% \mathrm{EE})$, and (AE). It is noticed that all three extracts (99.9\%EE), (80\%EE), and (AE) show a potent urease inhibitory activity with (IC50 $=$ $402.8,95.8$, and $348 \mathrm{mg} / \mathrm{L}$ ) respectively as compared with Thio urea which exhibits $(\mathrm{IC} 50=54077 \mathrm{mg} / \mathrm{L})$.

The IC50 Values of Extracts and the standard thiourea as urease inhibitor in pure urease enzyme are shown in table 6 .

The crudes based flavonoids were extracted by using $80 \%$ ethanol, $99 \%$ ethanol, and water. Three of flavonoids: Rutin, Kaempferol, and Quercetin were detected using reversed phase HPLC. The 99\% ethanol was able to extract only Quercetin; whereas, the Aqueous was able to extract Rutin and Kaempferol; but only $80 \%$ ethanol could extract such three flavonoids. It was found that water solvent gives higher yields than others; which can be considered as a factor causes solvent cost reduction. As well as, the three extracts of the corn silk were utilized in the inhibition of urease enzyme, it turned out that $80 \%$ ethanolic extract exhibited a highest efficient inhibition of pure urease enzyme and Klebsiella species urease; as compared with 99\% ethanol and the Aqueous.

\section{Acknowledgment}

My full thanks are presented to Dr. Wesen A. Mehdi, Dr. Perry A. Afaq, Dr. Suhail N. Abdullah and my sister Dr. Alyaa H. Ismail for his assistance and encouragement throughout this study.

\section{References}

1. Hu, Q. L., Zhang, L. J., Li, Y. N., Ding, Y. J., and Li, F. L. (2010). Purification and antifatigue activity of flavonoids from corn silk. International Journal of Physical Sciences, $5(4), 321-326$.

2. Cuina, W., Tiehua, Z., Jun, L., Shuang, L., Cheng, Z., Erlei, W., and Jingbo, L. (2011). Subchronic toxicity study of corn silk with rats. J. Ethnopharmacol.

3. Chen, S., Chen, H., Tian, J., Wang, Y., Xing, L., and Wang, J. (2013). Chemical modification, antioxidant and $\alpha$-amylase inhibitory activities of corn silk polysaccharides. Carbohydrate polymers, 98(1), 428-437.

4. Sarepoua, E., Tangwongchai, R., Suriharn, B., and Lertrat, K. (2013). Relationships between phytochemicals and antioxidant activity in corn silk.International Food Research Journal, 20(5), 2073-2079.

5. Nessa, F., Ismail, Z., and Mohamed, N. (2012). Antimicrobial activities of extracts and flavonoid glycosides of corn silk (Zea mays L). International Journal of Biotechnology for Wellness Industries, 1(2), 115-120.

6. Solihah, M. A., Wan Rosli, W. I., and Nurhanan, A. R. (2012). Phytochemicals screening and total phenolic content of Malaysian Zea mays hair extracts.

7. Procházková, D., Boušová, I., and Wilhelmová, N. (2011). Antioxidant and prooxidant properties of flavonoids. Fitoterapia, 82(4), 513-523. 
8. Ren, S. C., Qiao, Q. Q., and Ding, X. L. (2013). Antioxidative Activity of Five Flavones Glycosides from Corn Silk (Stigma maydis). Czech Journal of Food Science, 31(2).

9. Nurhanan, A. R., and Wan Rosli, W. I. (2013). Evaluation of Polyphenol Content and Antioxidant Activities of Some Selected Organic and Aqueous Extracts of Cornsilk (Zea mays Hairs). Journal of Medical and Bioengineering (JOMB), 1(1), 47-50.

10. Panchal, S. K., Poudyal, H., Arumugam, T. V., and Brown, L. (2011). Rutin attenuates metabolic nonalcoholicsteatohepatitis, changes, cardiovascular remodeling in highcarbohydrate, high-fat diet-fed rats. The Journal of nutrition, 141(6), 1062-1069.

11. Huang, W. W., Chiu, Y. J., Fan, M. J., Lu, H. F., Yeh, H. F., Li, K. H.,... and Yang, J. S. (2010). Kaempferol induced apoptosis via endoplasmic reticulum stress and mitochondria- dependent pathway in human osteosarcoma U- 2 OS cells. Molecular nutrition and food research, 54(11), 15851595.

12. Nabavi, S. F., Russo, G. L., Daglia, M., and Nabavi, S. M. (2015). Role of quercetin as an alternative for obesity treatment: you are what you eat. Food chemistry, 179, 305-310.

13. Nabavi, S. M., Nabavi, S. F., Eslami, S., and Moghaddam, A. H. (2012). In vivo protective effects of quercetin against sodium fluorideinduced oxidative stress in the hepatic tissue. Food Chemistry, 132(2), 931-935.

14. Zeng, H., Wang, Y., Kong, J., Nie, C., and Yuan, Y. (2010). Ionic liquid-based microwave-assisted extraction of rutin from
Chinese medicinal plants.Talanta, 83(2), 582590.

15. Javed, H., Khan, M. M., Ahmad, A., Vaibhav, K., Ahmad, M. E., Khan, A., and Safhi, M. M. (2012). Rutin prevents cognitive impairments by ameliorating oxidative stress and neuroinflammation in rat model of sporadic dementia of Alzheimer type. Neuroscience, 210, 340-352.

16. Lee, K. M., Lee, K. W., Jung, S. K., Lee, E. J., Heo, Y. S., Bode, A. M.,... and Dong, Z. (2010). Kaempferol inhibits UVB-induced COX-2 expression by suppressing Src kinase activity. Biochemical pharmacology, 80(12), 2042-2049.

17. Iyer, R., Iken, B., and Damania, A. (2017). Whole genome of Klebsiella aerogenes PX01 isolated from San Jacinto River sediment west of Baytown, Texas reveals the presence of multiple antibiotic resistance determinants and mobile genetic elements. Genomics Data.

18. Krajewska, B. (2009). Ureases I. Functional, catalytic and kinetic properties: A review. Journal of Molecular Catalysis B: Enzymatic, 59(1), 9-21.

19. Burne, R. A., and Chen, Y. Y. M. (2000). Bacterial ureases in infectious diseases. Microbes and Infection, 2(5), 533-542

20. AJ Awllia, J., Al-Ghamdi, M., Huwait, E., Javaid, S., Rasheed, S., and Iqbal Choudhary, M. (2016). Flavonoids as Natural Inhibitors of Jack Bean Urease Enzyme. Letters in Drug Design and Discovery, 13(3), 243-249.

21. Liu, J., Wang, C., Wang, Z., Zhang, C., Lu, S., and Liu, J. (2011). The antioxidant and free-radical scavenging activities of extract and fractions from corn silk (Zea mays L.) and related flavone glycosides. Food Chemistry, 126(1), 261-269.

\section{How to cite this article:}

Rafah H. Ismael, Salman A. Ahmed and Suhad S. Mahmoud. 2017. Detection of Rutin, Kaepferol, and Quercetin based Crude from Corn Silk and Studying their Effects on the Inhibition of Pure Urease Enzyme and Urease of Klebsiella Species. Int.J.Curr.Microbiol.App.Sci. 6(11): 2676-2685. doi: https://doi.org/10.20546/ijcmas.2017.611.315 